\title{
Strategy of Local Government in Household Waste Management in Jatinangor District Sumedang Regency West Java Province
}

\author{
Fernandes Simangunsong ${ }^{1}$, Amelia Fajarwati ${ }^{2}$ \\ ${ }^{1}$ Institut Pemerintahan Dalam Negeri (Governmental Institute of Home Affairs), Sumedang, Indonesia \\ ${ }^{2} J 1$. Raya Bandung-Sumedang, Sumedang, Indonesia \\ Email: kisankiel@yahoo.co.id, fernandes_simangunsong@ipdn.ac.id, fajarwatiamelia29@gmail.com
}

How to cite this paper: Simangunsong, F. and Fajarwati, A. (2018) Strategy of Local Government in Household Waste Management in Jatinangor District Sumedang Regency West Java Province. Open Journal of Social Sciences, 6, 63-87.

https://doi.org/10.4236/jss.2018.69005

Received: July 29, 2018

Accepted: August 31, 2018

Published: September 3, 2018

Copyright ( 92018 by authors and Scientific Research Publishing Inc. This work is licensed under the Creative Commons Attribution International License (CC BY 4.0).

http://creativecommons.org/licenses/by/4.0/

\begin{abstract}
This research focuses on determining and analyzing the strategy of Local Government in Household Waste Management, supporting and inhibiting factors of strategy of Local Government in Household Waste Management and efforts to overcome the inhibiting factors of strategy of Local Government in Household Waste Management in Jatinangor District, Sumedang Regency, West Java Province. Research method used was descriptive with qualitative approach and by analyzing data inductively. Data collection techniques used were interview, observation, documentation and triangulation. Analysis technique used was SWOT analysis by determining internal strategic factors to identify strengths and weaknesses, and external strategic factors to identify opportunities and threats as basis to determine objective and formulation of the strategy. SWOT matrix was used to formulate strategic issues and Litmus Test was, then, used to make priority on selected strategies. Based on results of research, it can be concluded that strategy of Local Government in household waste management in Jatinangor District, Sumedang Regency, West Java Province has not been well implemented, as seen by low competence of apparatus, lack of facilities and infrastructures to support the operational activities, lack of promotion of regional regulation on waste management and lack of public participation in household waste management. Deriving from conditions above, 20 strategies were formulated, by developing the SWOT concept and Litmust Test, to be used by Local Government for waste management.
\end{abstract}

\section{Keywords}

Strategy, Local Government, Household Waste Management 


\section{Introduction}

Law No. 23 of 2014 on Local Government states that "Local Administration is implementation of administrative affairs in accordance with principles of regional autonomy and duty of providing assistance, and shall exercise the broadest possible autonomy within the system and principle of Unitary State of the Republic of Indonesia as defined in the 1945 Constitution of the Republic of Indonesia". Application of regional autonomy is aimed to facilitate the even distribution of development across the country. Regional autonomy will improve basic services according to public needs of each region. In accordance with Law No. 23 of 2014 on Local Government, mandatory basic services shall include public works and spatial plannizng that also covers waste affairs [1].

Sumedang Regency Government is administrator of local governance in West Java Province which one of its duties is to deliver service in waste sector. Local Government Agency (Satuan Kerja Perangkat Daerah) authorized to control and manage waste affairs is Environmental Agency (Badan Lingkungan Hidup, or $B L H)$ which nomenclature is changed and then incorporated with Forestry Agency as Environmental and Forestry Agency. This change of nomenclature is in accordance with Regional Regulation of Sumedang Regency No. 11 of 2016 on Formation and Structure of Local Agency of Sumedang Regency. Environmental and Forestry Agency of Sumedang Regency has strategy and policy for 2014-2018 on Waste Affairsas presented in Table 1.

In order to help enabling environmental cleanliness that is free of waste, Sumedang Regency Government has formed Work Team for Water Supply and Environmental Sanitation (Kelompok Kerja Air Minum dan Penyehatan Lingkungan) through Decree of Sumedang Regent No. 440/KEP.240/BAPPPPEDA/2017, which one of its duties is to coordinate programs and activities in Sector of Water Supply and Sanitation in each Regional Bureaucracy (Organisasi Perangkat Daerah, or $O P D)$. Membership of the work team includes Head of Environmental and Forestry Agency of Sumedang Regency, Head of Waste and Park Affairs Division, and Head of Partnership Development for Waste Management Section.

Sumedang Regency is experiencing social and cultural and environmental issues, such as waste problems, due to increasing population each year. The increasing population contributes to increase of waste volume produced. Manik argues that, "Uncontrolled population increase causes problems in land supply for settlements and business, facilities for social and other socio-cultural services" [2].

"Asian developing countries are experiencing in increasing population, income and urban growth. This situation contributes to the increase of Solid Waste volume and type. Most of municipal solid waste comes from residential areas, commerce and other source" [3].

In accordance with Law No. 18 of 2008 on waste management, waste is unwanted solid by-products of human daily activities and/or natural process. And 
Table 1. Purpose, objective, strategy and policy in waste sector.

\begin{tabular}{cccl}
\hline Purpose & Objective & Strategy & \multicolumn{1}{c}{ Policy } \\
\hline 1 & 2 & 3 & 4 \\
\hline $\begin{array}{c}\text { To improve waste } \\
\text { management }\end{array}$ & $\begin{array}{c}\text { Waste heap } \\
\text { problem is solved }\end{array}$ & $\begin{array}{c}\text { Improvement of } \\
\text { waste management }\end{array}$ & $\begin{array}{l}\text { 2. Provide waste facilities and } \\
\text { infrastructures } \\
\text { 3. Pacilitate community in waste }\end{array}$ \\
& & & $\begin{array}{l}\text { 3. Felop the waste service area } \\
\text { management }\end{array}$ \\
\hline
\end{tabular}

Source: Strategic Plan of Environmental and Forestry Agency of Sumedang Regency Tahun 2014-2018.

household waste originates from daily activities of household, excluding feces and specific wastes [4].

Based on data above (Table 2), highest amounts of waste heap is produced in North Sumedang District and Jatinangor District, with population size of 105,427 people in North Sumedang District producing 111,752 liters/day and 100,961 people in Jatinangor District producing 107,019 liters/day. The fact is that the more the population size contributes to the more amount of waste volume produced. Based on study by Environmental Health Risk Assessment (EHRA) of Sumedang Regency on respondents in Sumedang Regency about waste management, the results are as follow (Table 3) [5].

According to results of the study, $90.62 \%$ of respondents consider that waste management in Sumedang Regency is still inadequate. $73.68 \%$ of respondents consider that frequency of waste transport is already adequate, $68.42 \%$ of them state that waste transport is time accurate, and $71 \%$ of them assert that the waste is not processed.

Waste management activities in districts are implemented by each Local Technical Implementation Unit (Unit Pelaksana Teknis Daerah or UPTD), such as Local Technical Implementation Unit (UPTD) for waste affairs in Jatinangor. Jatinangor District became an education area since one of main functions of Bandung City as an education city was relocated to Jatinangor District. As stated in Decree of West Java Governor No. 583/SK-PIL/1989 on Appointment of Jatinangor as higher education area, Local Government of West Java Province changes the function and purpose of former farm land of Jatinangor as complex of higher education which was previously centered in Bandung City as well as conservation area and greenbelt. Furthermore, in order to have better legal basis and certainty, Decree of West Java Governor No. 583/SK-PIL/1989 was made into Regional Regulation, i.e. Regional Regulation of West Java Province No. 11 of 1992 on Designation of Former Farm Land of Jatinangor in Level II Region of Sumedang Regency [6].

In Jatinangor, as an education area, problem of waste especially household waste is unavoidable. This is due to poor implementation of waste management. In accordance with Law No. 18 of 2008 on Waste Management, what is meant by waste management is systematic, comprehensive and continuous activities that 
Table 2. Volume of waste heap per district in Sumedang regency.

\begin{tabular}{|c|c|c|c|c|c|c|}
\hline \multirow{3}{*}{ Name of District } & \multicolumn{3}{|c|}{ Population Size (People) } & \multicolumn{3}{|c|}{ Volume of Waste (liters/day) } \\
\hline & \multirow{2}{*}{ Size } & \multicolumn{2}{|c|}{ Area } & \multicolumn{2}{|c|}{ Area } & \multirow{2}{*}{ Total } \\
\hline & & Urban & Rural & Urban & Rural & \\
\hline 1. Jatinangor & 100,961 & 67,702 & 33,259 & 71,764 & 35,255 & 107,019 \\
\hline 2. Cimanggung & 81,762 & 18,370 & 63,392 & 19,472 & 67,196 & 86,668 \\
\hline 3. Tanjungsari & 81,746 & 13,041 & 68,705 & 13,824 & 72,827 & 86,651 \\
\hline 4. Sukasari & 33,736 & - & 33,736 & - & 35,760 & 35,760 \\
\hline 5. Pamulihan & 59,713 & - & 59,713 & - & 63,296 & 63,296 \\
\hline 6. Rancakalong & 42,956 & - & 42,956 & - & 45,534 & 45,534 \\
\hline 7. South Sumedang & 78,930 & 44,210 & 34,720 & 46,862 & 36,803 & 83,665 \\
\hline 8. North Sumedang & 105,427 & 38,146 & 67,281 & 40,435 & 71,317 & 111,752 \\
\hline 9. Ganeas & 25,613 & - & 25,613 & - & 27,150 & 27,150 \\
\hline 10. Situraja & 41,363 & 2993 & 38,370 & 3172 & 40,673 & 43,845 \\
\hline 11. Cisitu & 30,813 & - & 30,813 & & 32,662 & 32,662 \\
\hline 12. Darmaraja & 43,581 & 4189 & 39,392 & 4440 & 41,755 & 46,195 \\
\hline 13. Cibugel & 24,777 & - & 24,777 & - & 26,263 & 26,263 \\
\hline 14. Wado & 52,658 & - & 52,658 & - & 55,817 & 55,817 \\
\hline 15. Jatinunggal & 46,777 & - & 46,777 & - & 49,584 & 49,584 \\
\hline 16. Jatigede & 26,023 & - & 26,023 & - & 27,584 & 27,584 \\
\hline 17. Tomo & 26,458 & - & 26,458 & - & 28,046 & 28,046 \\
\hline 18. Ujungjaya & 34,452 & - & 34,452 & - & 36,519 & 36,519 \\
\hline 19. Conggeang & 32,607 & - & 32,607 & - & 34,564 & 34,564 \\
\hline 20. Paseh & 38,978 & - & 38,978 & - & 41,316 & 41,316 \\
\hline 21. Cimalaka & 65,524 & - & 65,524 & - & 69,455 & 69,455 \\
\hline 22. Cisarua & 21,697 & - & 21,697 & - & 22,999 & 22,999 \\
\hline 23. Tanjungkerta & 37,105 & - & 37,105 & - & 39,331 & 39,331 \\
\hline 24. Tanjungmedar & 28,545 & - & 28,545 & - & 30,257 & 30,257 \\
\hline 25. Buahdua & 35,907 & - & 35,907 & - & 38,061 & 38,061 \\
\hline 26. Surian & 12,564 & - & 12,564 & - & 13,318 & 13,318 \\
\hline SUMEDANG REGENCY & $1,210,672$ & 188,651 & $1,022,021$ & 199,970 & $1,083,342$ & $1,283,312$ \\
\hline
\end{tabular}

Result of analysis by Work Team of Sanitation, 2015. Note: Waste Heap: 1.05 liters/day/people.

include waste reduction and treatment. Management of household waste and other similar types of waste includes waste reduction and waste treatment.

1) Waste reduction includes activities:

a) Reduce of waste heap;

b) Recycle of waste; and/or

c) Reuse of waste.

2) Waste treatment includes: 
Table 3. Waste Risk Area based on result of study of EHRA.

\begin{tabular}{ccc}
\hline Activity & Result of Study & Percentage \\
\hline $\mathbf{1}$ & $\mathbf{2}$ & $\mathbf{3}$ \\
\hline Waste Management & Inadequate & 90.62 \\
Frequency of Transport & Adequate & 9.38 \\
& Inadequate & 26.32 \\
Time Accuracy of Transport & Adequate & 73.68 \\
& Inaccurate & 31.58 \\
Local Processing & Yes, Accurate & 68.42 \\
& Not Processed & 71.08 \\
& Yes, Processed & 28.92 \\
\hline
\end{tabular}

Source: Study Report of Environmental Health Risk Assessment (EHRA) of Sumedang Regency, 2015.

a) Sorting of waste by categorizing and separating waste according to material, volume, and/or certain characteristic;

b) Collection of waste by taking and transporting waste from the source to landfill or integrated waste treatment facility;

c) Transporting by taking waste from the source and/or landfill or integrated waste treatment facility to waste processing site;

d) Processing by changing the characteristics, composition, volume of waste; and/or final processing by returning of waste and/or residue of processed waste to environmental medium safely

Waste management activities by Local Technical Implementation Unit for waste affairs of Jatinangor area are scheduled waste collection in Jatinangor area and transported by waste vehicle. There are 2 (two) units of waste vehicle, i.e. one unit of dump truck and one unit of amroll. One unit of dump truck is lent by Local Technical Implementation Unit for waste affairs to Komunitas Peduli Sampah Jatinangor (KPS) (literally translated to English as Jatinangor Waste Care Community) in order to help waste collection service that can not be offcially provided along arterial road. In waste management activities, the number of waste truck is considered insufficient for waste transport from Jatinangor to waste processing site (Tempat Pembuangan akhir, or TPA) in Sumedang. Omay Komarudin, Head of Local Technical Implementation Unit for waste affairs of Jatinagor area states that, "waste volume of Jatinangor, Tanjungsari and Cimanggung is fairly high. On the other hand, there are only two units of waste truck" [7]. This makes waste management hindered because process of waste transfer from source to waste processing site can only be done, at most, twice a day.

As shown in Table 4, this schedule of waste collection in Jatinangor Area made by Local Technical Implementation Unit for waste affairs of Jatinangor area has been supporting waste management activities; however, this still fails to reduce waste volume produced by community in Jatinangor. Waste volume 
Table 4. Schedule of waste service in Jatinangor Area.

\begin{tabular}{ccllc}
\hline Day & Time & \multicolumn{1}{c}{ Location } & \multicolumn{1}{c}{$\begin{array}{c}\text { Name of } \\
\text { Driver }\end{array}$} & $\begin{array}{c}\text { Field } \\
\text { Officer }\end{array}$ \\
\hline $\mathbf{1}$ & $\mathbf{2}$ & \multicolumn{1}{c}{$\mathbf{3}$} & \multicolumn{1}{c}{$\mathbf{4}$} & $\mathbf{5}$ \\
\hline Monday & 05.30 & -JATOS & -Nana R & Masrizal \\
& 13.30 & -Komp. PUSKOPAD & -Iding & \\
Tuesday & 06.30 & -Komp. SBG & -Nana R & Masrizal \\
& 13.30 & -Komp. PUTRAKO & -Iding & \\
Wednesday & 05.30 & -JATOS & -Iding & Masrizal \\
& 13.30 & -RW. 09 Griya Jatinangor I & -Nana R & \\
Thursday & 06.30 & -RW. 09 Griya Taman Lestari & -Iding & Masrizal \\
& 13.30 & -Komp. Alam Lestari & -Nana R & \\
Friday & 05.30 & -RW. 13 Griya Jatinangor II & -Nana R & Masrizal \\
& 13.30 & -RW 14 & -Iding & \\
Saturday & 05.30 & -JATOS & -Iding & Masrizal \\
& 13.30 & -RW 10 Griya Jatinangor I & -Nana R & \\
\hline
\end{tabular}

Source: Local Technical Implementation Unit for Waste Affairs of Jatinangor Area, 2017.

produced by community in Jatinangor, in total, reaches $980 \mathrm{M}^{3}$ per month. In average, waste volume produced in Jatinangor District is $32.6 \mathrm{M}^{3} /$ day.

As shown in Table 5, waste produced in Jatinangor mostly derives from local residences, apartments, and rent student rooms. Amount of waste produced is approximately 12 tons/day; however, this amount would be reduced according to student activities and academic schedule. As explained by Head of Local Technical Implementation Unit (UPTD) for waste affairs of Jatinangor area, Omay Komarudin, "Obviously, the amount of 12 tons per day might approximately reduced by $30 \%$ with certain conditions," according to him, "it usually happens every once a year due to, such as, academic schedule and moment of Eid al-Fitr holiday that the waste volume decreases" [8]. Continuously increasing waste volume produced in Jatinangor, unfortunately, is not counterbalanced with proportional reduce of waste by community. Currently, waste bank is common thing, which is aimed to help community to reduce waste by means of waste recycle and reuse; however, waste bank in Jatinangor itself receives less response from government since there is only one waste bank built by private sector in Jatinangor, i.e. Bank Sampah Bersinar located in Sayang village.

Jatinangor District already has Integrated Waste Treatment Facility (Tempat Pengolahan Sampah Terpadu or TPST) located in Hegarmanah village which was inaugurated by Regent of Sumedang at beginning of January 2017. Waste management at the Integrated Waste Treatment Facility (TPST) of Hegarmanah village only receives waste from Hegarmanah village. Without Landfill (tempat penampungan sampah or TPS) in Jatinangor area the community to dispose of waste on empty land and on river or to put waste along the road before being taken by waste collector. According to Government Regulation No. 81 of 2012 on management of household waste and other similar types of waste, it is stated that regency/city government shall provide Landfill and/or 3Rs Landfill at settlement areas. Landfill with principle of 3Rs (reduce, reuse, recycle), hereinafter 
Table 5. Waste volume of UPTD of environmental and forestry unit of Jatinangor Area.

\begin{tabular}{ccccc}
\hline No. & District & Village & $\begin{array}{c}\text { Number of HoF } \\
\text { (Head of Family) }\end{array}$ & $\begin{array}{c}\text { Waste } \\
\text { Volume/Month }\end{array}$ \\
\hline 1 & 2 & $\mathbf{3}$ & $\mathbf{4}$ & $\mathbf{5}$ \\
\hline & 1. Cipacing & 3249 & $100 \mathrm{M}^{3}$ \\
& 2. Sayang & 3286 & $70 \mathrm{M}^{3}$ \\
& 3. Mekargalih & 2386 & $100 \mathrm{M}^{3}$ \\
& 4. Cintamulya & 5530 & $90 \mathrm{M}^{3}$ \\
& 5. Cisempur & 2900 & $100 \mathrm{M}^{3}$ \\
& 6. Jatimukti & 2120 & $60 \mathrm{M}^{3}$ \\
& 7. Jatiroke & 2429 & $60 \mathrm{M}^{3}$ \\
& 8. Hegarmanah & 1624 & $100 \mathrm{M}^{3}$ \\
& 9. Cikeruh & 2868 & $90 \mathrm{M}^{3}$ \\
& 10. Cibeusi & 1982 & $90 \mathrm{M}^{3}$ \\
& 11. Cileles & 2094 & $60 \mathrm{M}^{3}$ \\
& 12. Cilayung & 1677 & $60 \mathrm{M}^{3}$ \\
\hline
\end{tabular}

Source: Local Technical Implementation Unit for Waste Affairs of Jatinangor, 2017.

referred to as 3Rs Landfill, is place for collection, sorting, reuse, and recycle of waste with the scale of area. Lack of waste recycle and reuse is one of factors of high volume of waste produced by community in Jatinangor District. As shown in Figure 1.

As an area that contributes to fairly high volume of waste heap, Jatinangor District becomes one of high and very high waste-risk areas. This certainly draws special attention on how to decrease waste-risk in Jatinangor area. Waste management in Jatinangor District itself is administered by Local Technical Implementation Unit (UPTD) for waste fair of Jatinangor area with cooperation with Komunitas Peduli Sampah Jatinangor (KPS) (or literally translated to English as Jatinangor Waste Care Community). Komunitas Peduli Sampah Jatinangor (KPSJ) was formed in order to help reduce of waste in Jatinangor area. As shown in Figure 2.

As shown in Table 6, Waste Processing Site (Tempat Pembuangan Akhir or $T P A$ ) in Sumedang Regency is located at the foot of Tampomas mountain in Cibereum Wetan Village, Cimalaka District. Waste management at Waste Processing Site in Sumedang Regency, since its construction in 1997 to today, uses Open Dumping system. Waste management, from the source to Waste Processing Site, still uses transport and dump system, i.e. only transport waste and dump the waste at Waste Processing Site without any further processing.

Law No. 18 of 2008 states that waste management at Waste Processing Site $(T P A)$ shall not use open dumping system anymore but, instead, it shall use controlled landfill method (method to compact and cover the waste with soil). This indicates that waste management at Waste Processing Site (TPA) of Cibereum 


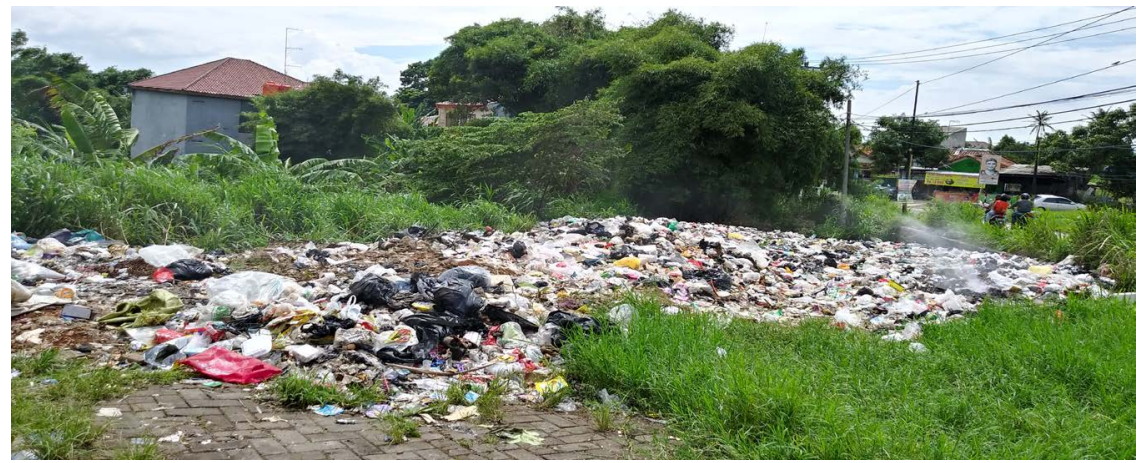

Figure 1. Waste in Sayang village. Source: Documentation by author.

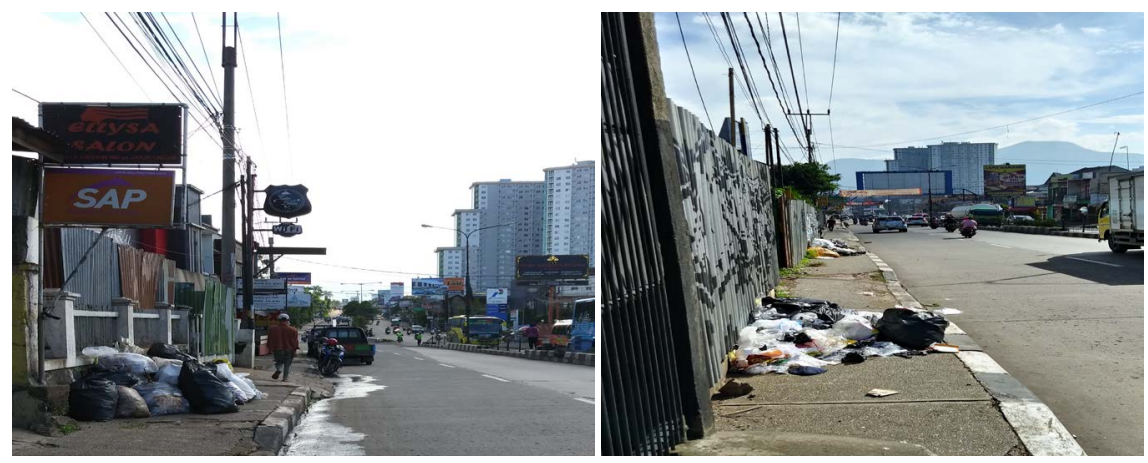

Figure 2. Waste along Jatinangor arterial road. Source: Documentation by author.

Table 6. Village/subdistrict with risk in waste sector.

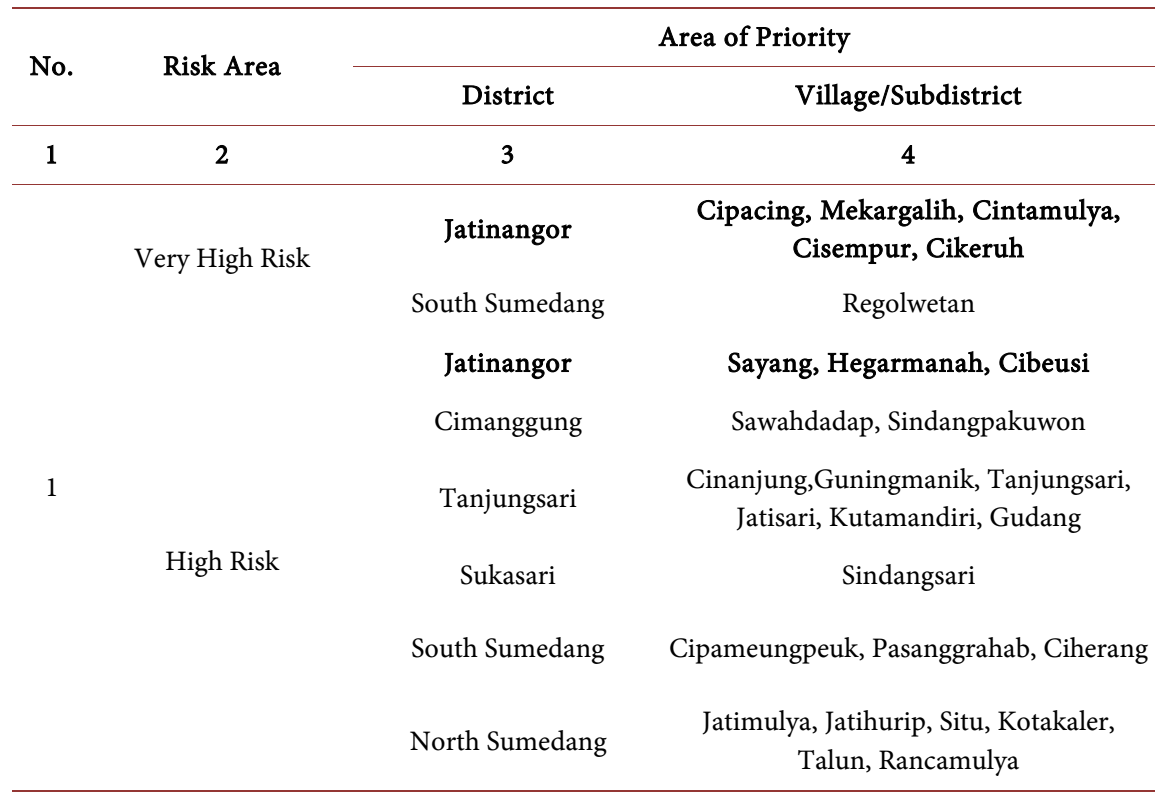

Source: Update of Sanitation Strategy of Sumedang Regency, 2015.

is not proper for use anymore. Sumedang Regency Government already has regulation on waste affairs, i.e. Regional Regulation No. 2 of 2014 on Management of Household Waste and Other Similar Types of Waste in Sumedang Regency. This regulation aims to turn waste into resources with positive impact on quality 
of environment, public health and economy. This regulation also regulates criminal sanction, i.e. imprisonment for a maximum of 3 (three) months or fine for a maximum of Rp50,000,000 (fifty million rupiahs) on people who dispose of waste improperly [9]. As a legal basis, Regional Regulation No. 2 of 2014 on Management of Household Waste and Other Similar Types of Waste in Sumedang Regency should be feasibly implemented. Below is results of analysis on management of household waste in Sumedang Regency, as shown in Table 7.

In Regional Regulation No. 2 of 2014 on Management of Household Waste and Other Similar Types of Waste in Sumedang Regency, Article 44, it is stated that no one shall be allowed to: (b) dispose of waste on environmental medium or inappropriate place; and (f) burn waste on land in the open which does not meet technical requirement of waste management. This problem is resulted from regional regulation on waste management that is not promoted evenly to public. Promotion on waste management is administered by Work Team for Water Supply and Environmental Sanitation (Kelompok Kerja Air Minum dan Penyehatan Lingkungan or $A M P L$ ) once every 3 months or at least twice a year. However, the promotion is still limited within Sumedang City and not yet to every community in all districts in Sumedang. Promotion in the districts is still limited to representatives of community. And sanction given to people who dispose of waste improperly is still limited to warning and correctional. Sanction given is supposedly according to regional regulation enacted.

Waste problem in Jatinangor is crucial, considering that the waste produced by community will have both personally and environmentally bad effects without proper treatment. Effects of the waste for individual are health problems by which waste heap will become source of diseases and results in diseases such as diarrhea, respiratory problems, and skin diseases. As for environment, waste along arterial road will be aesthetically annoying, and the waste clogs drainage which eventually results in flood, such as dispose of waste on river in Jatinangor may result in flood in Rancaekek District.

Table 7. Management of household waste.

\begin{tabular}{ccc}
\hline No. & Management of Household Waste & Percentage \\
\hline 1 & 2 & 3 \\
1 & Not knowledgeable & 0.18 \\
2 & Others & 0.63 \\
3 & Disposed to empty land/field & 12.57 \\
4 & Disposed to river/drainage & 6.06 \\
5 & Disposed to hole and not covered with soil & 1.63 \\
6 & Disposed to hole and covered with soil & 0.72 \\
7 & Burned & 68.81 \\
8 & Collected and disposed to Landfill & 7.69 \\
9 & Collected to informal waste collector & 1.72 \\
\hline
\end{tabular}

Source: Study of EHRA (Environmental Health Risk Assessment) of Sumedang Regency, 2015. 
Factually, according to Strategic Plan of Environmental and Forestry Agency of Sumedang Regency on waste management, waste condition in Jatinangor area requires special attention and more advanced formulation of strategy and efforts for problems in management of waste, especially household waste. Based on elaboration above, we are interested to do research titled "Strategy of Local Government in Household Waste Management in Jatinangor District, Sumedang Regency, West Java Province".

\section{Problem Statement}

In relation with facts above, problem statements as basis for this research are:

1) What is Strategy of Local Government in Household Waste Management in Jatinangor District, Sumedang Regency, West Java Province?

2) What are supporting and inhibiting factors in the Strategy of Local Government in Household Waste Management in Jatinangor District, Sumedang Regency, West Java Province?

3) What are efforts to overcome the inhibiting factors in Strategy of Local Government in Household Waste Management in Jatinangor District, Sumedang Regency, West Java Province?

\section{Theoretical Framework}

Theoretical framework explains structure of thinking used by researcher in doing research. In order to achieve good management of household waste, it requires certain strategy to be formulated in such a way. This research uses concept of strategy by Stephen P. Robbins and Mary Coulter, concept of waste management by George Tcobanoglous and Frank Kreith (with reference to Regional Regulation of Sumedang Regency on management of household waste and other similar types of waste) and SWOT analysis technique by Rangkuti to determine strategy of Local Government in household waste management in Jatinangor District, Sumedang Regency, West Java Province [10].

SWOT analysis technique used consists of Strengths, Weaknesses, Opportunities, and Threats with SO (Strengths and Opportunities) strategy, WO (Weaknesses and Opportunities) strategy, ST (Strengths and Threats) strategy, and WT (Weaknesses and Threats) strategy [11], and then identification of supporting and inhibiting factors using concept by Robbins. Litmus Tests is used to determine the most appropriate strategy and strategic issues to be implemented. Based on explanation above, theoretical framework is formulated according to Figure 3.

\section{Work Hypothesis}

Research of Strategy of Local Government in Household Waste Management in Jatinangor District, Sumedang Regency, West Java Province uses concept of strategy by Stephen P Robbins and Mary Coulter, concept of waste management by George Tcobanoglous and Frank Kreith and Rangkuti's concept of SWOT 


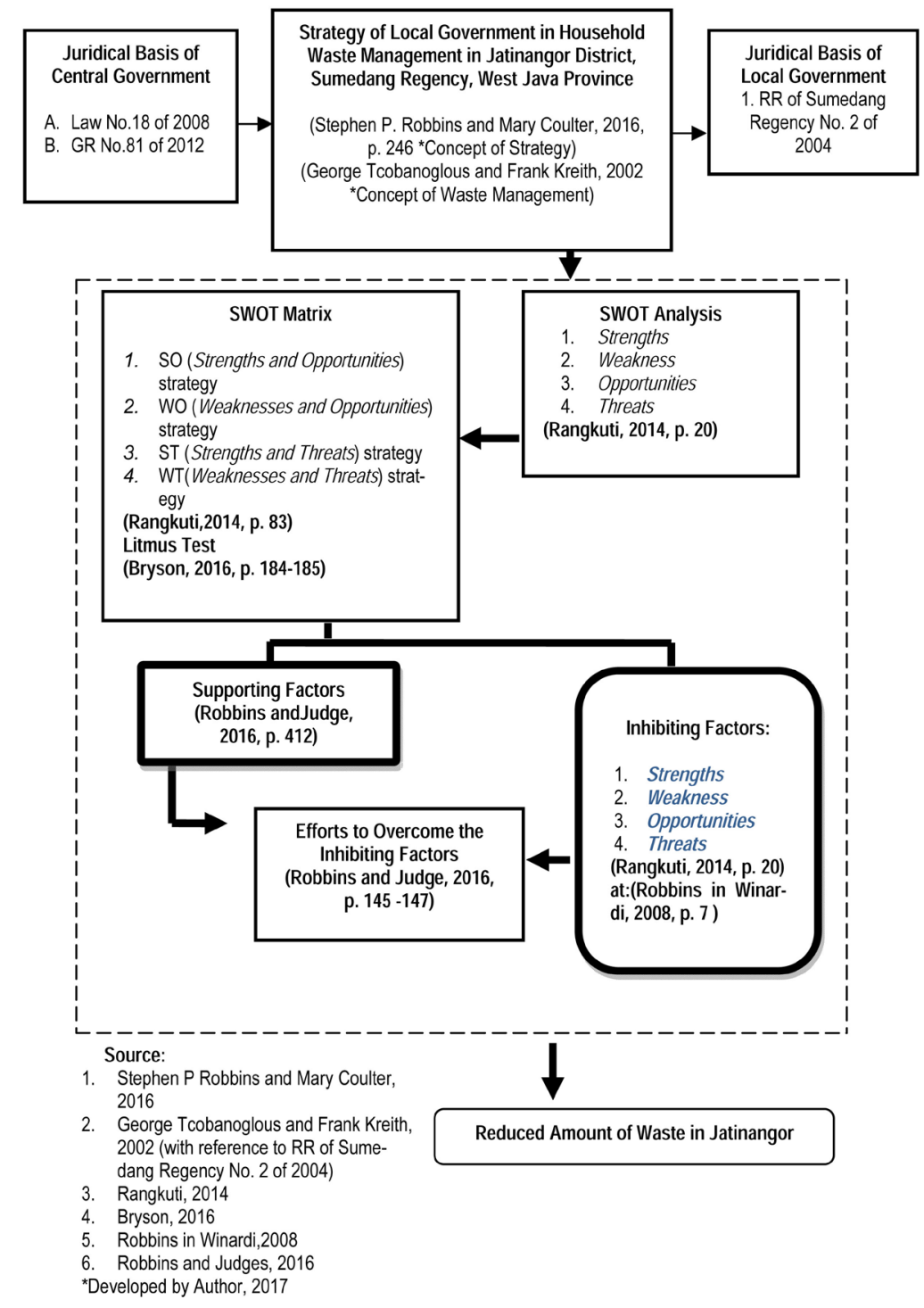

$--------=$ Focus of Research

Figure 3. Theoritical framework.

Analysis, (Strengths, Weaknesses, Opportunities, Threats) with SO (Strengths and Opportunities) strategy, WO (Weaknesses and Opportunities) strategy, ST (Strengths and Threats) strategi, and WT (Weaknesses and Threats) strategy.

Researcher identifies inhibiting factors using concept by Stephen Robbins (in Winardi) and supporting factors using concept by Stephen Robbins and developed by researcher, and efforts to overcome the inhibiting factors using concept by Stephen Robbins. This is done to determine appropriate strategy based on strategic issues identified, and Litmus Test is administered using concept by Bryson so that the strategy is feasibly implemented.

If strategy of Local Government in household waste management in Jatinangor District, Sumedang Regency, West Java Province can be well implemented, it 
is expected to amount of waste in Jatinangor can be decreased and made useful with methods of recycle and reuse.

\section{Research Method}

Simangunsong, in his book, says that research is included in perspective management which is research, like writing scientific, semi-scientific and even non-scientific paper, is an important intellectual activity and continuing process. Furthermore it is explained that, "Research of public administration is effort to determine, develop and test indications, facts, phenomena and dynamics of public administration in order to create validity of administrative science in the context of authority and public services in coherent, corresponding and pragmatical manners that derives from systematic thinking with theoretical, legalistic, empirical and innovative advantages." [12].

Based on explanation about characteristics of research and method used in research of public administration above, researcher uses qualitative method with descriptive-inductive approach to describe and analyze problems according to factual condition and relationship with existing phenomena so that conclusion can be drawn in order to find solution for the problems.

Departing from problems on the field, researcher develops theory with concept of strategy by Stephen P. Robbins and Marry Coulter, concept of waste management by George Tchobanoglous and Frank Kreith, and then incorporated into concept of SWOT analysis by Rangkuti. And concept by Robbins in Winari is used to determine supporting and also inhibiting factors, while concept by Robbins and Judges is used to determine efforts to overcome the inhibiting factors.

In this research (Table 8), informants were determined using purposive technique. Interview was conducted to informants, i.e. local government who are able to provide information and data accurately, and villagers in Jatinangor District where research was conducted. Informants in this research are:

1) Regent of Sumedang as informant 1 ;

2) Commission D of Division of Environment of Regional Legislative Council of Sumedang Regency as informant 2;

3) Regional Secretary of Sumedang Regency as informant 3;

4) Head of Regional Development Planning, Research and Development Agency of Sumedang Regency as informant 4;

5) Head of Environmental and Forestry Agency of Sumedang Regency as informant 5;

6) Head of Head of Waste and Park Affairs Division of Sumedang Regency as informant 6;

7) Head of Partnership Development for Waste Management Section, Environmental and Forestry Agency of Sumedang Regency as informant 7;

8) Local Technical Implementation Unit for Waste Affairs of Jatinangor area, Informant 8; 
Table 8. Research theme structure.

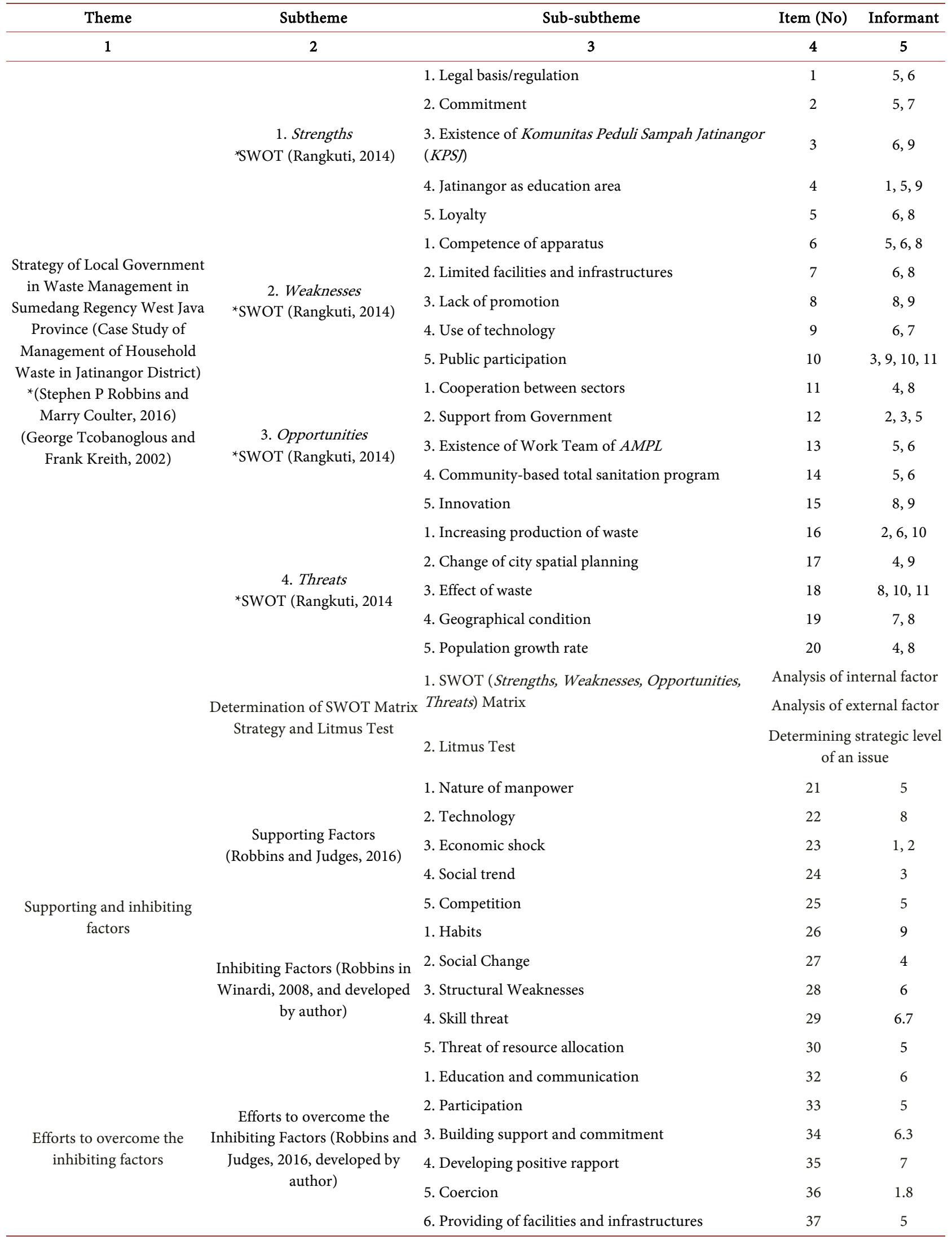


9) Head of Jatinangor District as informant 9;

10) Head of Integrated Waste Treatment Facility (TPST) of Sauyunan as informant 10;

11) Villagers in Jatinangor District chosen using purposive sampling as informants 11 .

And documents used to support analysis in this research are:

1) Documents:

a) Masterplan of Waste Affairs of Sumedang Regency (2011, projection for the next 10 years)

b) Urban Planning of Education City (Perencanaan Kawasan Perkotaan Kota Pendidikan or PKPKP) of Jatinangor, 2016

c) RPJMD (2014-2018) of Sumedang Regency

d) White Paper of Sanitation, SSK and Study of EHRA (2015, update in once every 5 years)

e) Strategic Planning (2014-2018), LAKIP(2017) DLHK of Sumedang

2) Regulations:

a) Law No. 18 of 2008 on Waste Management

b) GR No. 81 of 2012 on Management of Household Waste and Other Similar Types of Waste

c) RR of Sumedang Regency No. 2 of 2004 on Management of Household Waste and Other Similar Types of Waste in Sumedang Regency

SWOT analysis was also used by determining internal strategic factors to identify strengths and weaknesses, and external strategic factors to identify opportunities and threats as basis to determine objective and formulation of the strategy.

Steps to determine internal strategic factor (Internal Factor Analysis Summary or IFAS) are:

1) Determine factors in element of strengths and weaknesses to column 1 :

2) Define significance of each factor by score of from 1.0 (very significant) to 0.0 (not significant) based on influence of the factor on strategic position. Keep in mind that the total significance is not more than 1.0;

3) Calculate rating (column 3) for each factor by giving score of from 4 (Outstanding) to 1 (Poor) based on influence of the factor on condition of the organization. Variable with positive value, i.e. all variables included in strength, is given with score from +1 to +4 (very good) by comparing it to average score of organization's main competitor. And variable with negative value is contrariwise. If weakness of the organization is higher and more serious than average score of other similar organization, the score is 1 . On the contrary, if weakness of the organization is lower than average score of other organization, the score is 4 ;

4) Multiply significance value in column 2 to score in column 3 to get significance factor in column 4. The result is significance score for each factor with value varying from 4.0 to 1.0 .

5) Use column 5 to put comment or note on why certain factors are chosen 
and how the significance score is calculated.

6) Sum significance scores (column 4) to get total significance score for the organization. This total score shows how the organization reacts to its internal strategic factors. This score can be used to compare with other organization".

As shown in Table 9: Steps to determine external strategic factor (External Factor Analysis Summary or IFAS) are:

1) Set column 1 with 5 to 10 main opportunities and threats faced by the insitution.

2) Define significance of each factor in column 2 by score of from 0.0 (not significant) to 1.0 (very significant).

3) Calculate rating (column 3) for each factor by giving scale of from 1 (very low) to 4 (very high) based on influence of the factor on condition of the organization. For opportunities, value given is positive (eg. +4), and for threats, value is negative or contrariwise (e.g. -1).

4) Multiply significance value in column 2 to score in column 3 to get significance factor in column 4 . The result is significance score for each factor with value varying from +4 (very high) to +1 (very low).

5) Use column 5 to put comment or note according to score get.

6) Sum score in column 4 to get total score for the organization. This total score shows how the organization reacts to its external strategic factors. In addition, this total score can also be used to compare with other organization". As shown in Table 10 .

After rating significance acquired, next step is to formulate strategic issues by using a tool to set strategic factors, i.e. SWOT Matrix. This matrix can clearly describe how external opportunities and threats faced by organization should be matched with its strengths and weaknesses. As shown in Table 11.

1) SO Strategy

This strategy is used based on organization's way of thinking, i.e. by using all strengths to take and use most opportunities possible.

2) ST Strategy

This is strategy to use organization's strengths to overcome threats.

3) WO Strategy

This strategy is applied based on using available opportunities by minimizing weaknesses.

4) WT Strategy

Table 9. Internal factor analysis summary (IFAS).

\begin{tabular}{ccccc}
\hline Internal Strategic Factors & Significance & Rating & Significance $\times$ Rating & Comment \\
\hline 1 & 2 & 3 & 4 & 5 \\
Strength & - & 1 to 4 & - & - \\
Weakness & - & 1 to 4 & - & - \\
Total & 1.00 & - & - & - \\
\hline
\end{tabular}


Table 10. External factor analysis summary (EFAS).

\begin{tabular}{ccccc}
\hline External Strategic Factors & Significance & Rating & Significance x Rating & Comment \\
\hline 1 & 2 & 3 & 4 & 5 \\
Opportunity & - & 1 to 4 & - & - \\
Threat & - & 1 to 4 & - & - \\
Total & 1.00 & - & - & - \\
\hline
\end{tabular}

Table 11. SWOT matrix.

\begin{tabular}{|c|c|c|}
\hline EFAS & $\begin{array}{l}\text { STRENGTHS (S) } \\
\text { Define } 5 \text { - } 10 \text { internal factors of } \\
\text { weakness }\end{array}$ & $\begin{array}{l}\text { WEAKNESSES }(\mathrm{W}) \\
\text { Define } 5 \text { - } 10 \text { internal factors of } \\
\text { strength }\end{array}$ \\
\hline OPPORTUNITIES (O) & SO STRATEGY & WO STRATEGY \\
\hline $\begin{array}{l}\text { Define } 5 \text { - } 10 \text { external factors of } \\
\text { opportunity }\end{array}$ & $\begin{array}{l}\text { Create strategy that optimizes } \\
\text { strengths to use opportunities }\end{array}$ & $\begin{array}{l}\text { Create strategy that minimizes } \\
\text { weaknesses to use opportunities }\end{array}$ \\
\hline THREATS (T) & ST STRATEGY & WT STRATEGY \\
\hline $\begin{array}{l}\text { Define } 5 \text { - } 10 \text { external factors of } \\
\text { threat }\end{array}$ & $\begin{array}{l}\text { Create strategy that optimizes } \\
\text { strengths to overcome threats }\end{array}$ & $\begin{array}{l}\text { Create strategy that minimizes } \\
\text { weaknesses to avoid threat }\end{array}$ \\
\hline
\end{tabular}

Source: Rangkuti, 2014.

This strategy is based on defensive activities to minimize weaknesses and avoid threats".

In determining a strategy as an issue, we can use Litmus Test. Litmus Test is a technique used to determine how strategic an issue is. Bryson explains that when the strategic issues are identified, they should be sorted in order of priority, logic, or temporal order as basis for strategy development in the next stages" [13]. Furthermore, "Litmus Test used by Hennepin Country is to filter strategic issues. Issues which are very strategic are the ones with highest score in all dimensions". In Litmus Test, classification of scoring is set based on strategic issues provided to informants. Range of scoring for Litmus Test can be set for each item indicator to produce score of Litmus Test per strategic issue. Scoring in assessment by Litmus Test is as follows:

Score 1: Operational issue.

Score 2: Fairly strategic issue.

Score 3: Very strategic issue.

Based on highest score and lowest score acquired in scoring of strategic issues, the score ranges are as follows:

Total Score: 13 - 21 Operational issue.

Total Score: 22 - 30 Fairly strategic issue.

Total Score: 31 - 39 Very strategic issue.

Below is Table 12 of list of question in Litmus Test.

\section{Result}

Based on results of research of Strategy of Local Government in Waste Management in Sumedang Regency West Java Province with case study of management 
Table 12. List of question and score of litmus test (Operational $\longleftrightarrow$ Strategy).

\begin{tabular}{|c|c|c|c|c|}
\hline No. & Question & (1) & (2) & (3) \\
\hline 1. & $\begin{array}{l}\text { When does challenge or opportunity of the strategic issues } \\
\text { occur ahead of you? }\end{array}$ & Now & Next Year & $\begin{array}{c}\text { Two or more years from } \\
\text { now }\end{array}$ \\
\hline 2 & To how much extent will the issue affect the organization? & Singe division/unit & Several divisions & All departments \\
\hline 3 & $\begin{array}{l}\text { How much is your organization's financial } \\
\text { risk/opportunity? }\end{array}$ & Low & Medium & High \\
\hline \multirow[t]{6}{*}{4} & Will strategies for solution of the issues require: & & & \\
\hline & a) development of objective and program of service? & No & & Yes \\
\hline & b) Significant change in resource or amount of tax? & No & & Yes \\
\hline & c) Significant change in decision or regulation? & No & & Yes \\
\hline & d) Addition or modification of main facilities? & No & & Yes \\
\hline & e) Significant addition of staff? & No & & Yes \\
\hline 5 & What is the best approach for solution of the issues? & $\begin{array}{l}\text { Clear and ready to } \\
\text { implement }\end{array}$ & $\begin{array}{l}\text { Wide and rather detailed } \\
\text { parameter }\end{array}$ & Widely open \\
\hline 6 & $\begin{array}{l}\text { Which of the lowest management levels can decide how to } \\
\text { overcome the issues? }\end{array}$ & Line staff supervisor & Head of division & Head of department \\
\hline 7 & $\begin{array}{l}\text { What are the possible consequences if the issues are not } \\
\text { solved? }\end{array}$ & $\begin{array}{l}\text { There will be disorder of } \\
\text { inefficiency }\end{array}$ & $\begin{array}{l}\text { Disorder in services, loss } \\
\text { of financial resource }\end{array}$ & $\begin{array}{l}\text { Long term disorder in } \\
\text { services, and substantial } \\
\text { cost/declining income }\end{array}$ \\
\hline 8 & $\begin{array}{l}\text { How many other departments are affected by the issues } \\
\text { and involved in the solution? }\end{array}$ & None & One to three & Four or more \\
\hline 9 & $\begin{array}{l}\text { How is sensitiveness or charge of these issues to social, } \\
\text { political, religious, and cultural values of the community? }\end{array}$ & Soft & Medium & Hard \\
\hline
\end{tabular}

Source: John. M. Bryson, 2016.

of household waste in Jatinangor District, waste management in Jatinangor is still poorly implemented, and the strengths and opportunities owned by Sumedang Regency can be a support to overcome threats and weaknesses in activities of household waste management. Below are conclusions that can be drawn:

Strategy of Local Government in Waste Management:

\section{1) Strengths}

a) Waste management already has legal basis/regulation, i.e. Regional Regulation of Sumedang Regency No. 2 of 2004 on Management of Household Waste and Other Similar Types of Waste in Sumedang Regency;

b) Work commitment is built through family relationship;

c) Komunitas Peduli Sampah Jatinangor (KPS) has important role in environmental cleanliness of Jatinangor area;

d) Main asset of Jatinangor is its function as education area to prepare good quality human resources;

e) Government officials highly honor loyalty as form of compliance to workloads given.

2) Weaknesses

a) Competence of apparatus is still low thus unable to properly implement 
waste management;

b) Limited facilities and infrastructures in management of household waste in operational activities of waste affairs;

c) Lack of promotion on regulation results in lack of information and understanding on proper management of household waste;

d) Use of technology is not yet optimal in management of household waste;

e) Public participation in management of household waste is still low.

3) Opportunities

a) Cooperation between both public and private sectors through coordination can synergize programs in management of household waste;

b) Support from government through providing budget for waste management, support of regional regulation, and support of control in management of household waste;

c) Existence of work team for water supply and environmental sanitation (Air Minum dan Penyehatan Lingkungan or $A M P L)$ to synergize activities of waste management;

d) Program of ommunity-based total sanitation (Sanitasi Total Berbasis Masyarakat or $S T B M$ ) in form of waste bank;

e) Wide range of innovation in waste management.

4) Threats

a) Waste production is increasing each day;

b) Change of city spatial planning does not prepare land specified for management of household waste;

c) Effect of waste becomes public threat;

d) Geographical condition of Sumedang Regency becomes constraint in the process of household waste management;

e) Population growth rate contributes to amount of waste produced.

Based on analysis using SWOT matrix, the strategies are as follows:

1) S-O (Strengths-Opportunities) strategies are:

a) To establish waste bank in each village through cooperation between public and private sectors in accordance with prevailing regulations;

b) To be committed to implement management of household waste through social assistance;

c) To establish Memorandum of Understanding (MOU) with Komunitas Peduli Sampah Jatinangor (KPS) to help the implementation of community-based total sanitation program;

d) To support and implement program of Work Team of Water Supply and Environmental Sanitation $(A M P L)$ in waste management;

e) To create new innovations in management of household waste through cooperation between internal sectors, private sectors, higher education institutions and community;

2) W-O (Weaknesses-Opportunities) strategies are:

a) To improve quality of human resources to be competent in management of 
household waste through education and training;

b) To make use of social assistance to acquire necessary supporting facilities and infrastructures for management of household waste;

c) To implement promotion of community-based total sanitation program;

d) To facilitate the use of technology through development and training of household waste management;

e) To implement program of household waste management by improving facilities and infrastructures and maximizing the use of technology;

3) S-TO (Strengths-Threats) strategies are:

a) To reduce waste production with the use of environmentally friendly products and recycle of waste;

b) To be committed to continue making efforts to make change in management of household waste;

c) To support and facilitate KPSJ in waste management in order to avoid bad effects of waste;

d) Educational institutions should give idea contribution in solving the geographical problem of household waste management;

e) To improve cooperation between government and educational institutions in activities of household waste management;

4) W-T (Weaknesses-Threats) strategies are:

a) To implement training that improves skills of government apparatus in household waste treatment;

b) To educate community to familiarize themselves in sorting and making use of household waste from the smallest scope i.e. own house;

c) To launch promotional program of household waste management and effect of waste;

d) To use technology in coping with less supporting geographical condition for household waste management;

e) To stimulate community through activities that develop creativity and improve environmental awareness.

Twenty strategies based on S-O (Strengths-Opportunities) strategy, W-O (Weaknesses-Opportunities) strategy, S-T (Strengths-Threats) strategy and W-T (Weaknesses-Threats) strategy are tested by Litmus test to acquire strategic issues in management of household waste in Jatinangor, i.e.:

1) Very strategic issues

a) To establish waste bank in each village through cooperation between public and private sectors in accordance with prevailing regulations;

b) To establish Memorandum of Understanding (MOU) with Komunitas Peduli Sampah Jatinangor (KPS) to help the implementation of community-based total sanitation program;

c) To improve quality of human resources to be competent in management of household waste through education and training;

d) To implement promotion of community-based total sanitation program; 
e) To facilitate the use of technology through development and training of household waste management;

f) To implement program of household waste management by improving facilities and infrastructures and maximizing the use of technology;

g) To support and facilitate KPSJ in waste management in order to avoid bad effects of waste;

h) To improve cooperation between government and educational institutions in activities of household waste management;

i) To launch promotional program of household waste management and effect of waste;

2) Fairly strategic issues:

a) To create new innovations in management of household waste through cooperation between internal sectors, private sectors, higher education institutions and community;

b) To make use of social assistance to acquire necessary supporting facilities and infrastructures for management of household waste;

c) To reduce waste production with the use of environmentally friendly products and recycle of waste;

d) Educational institutions should give idea contribution in solving the geographical problem of household waste management;

e) To implement training that improves skills of government apparatus in household waste treatment;

f) To educate community to familiarize themselves in sorting and making use of household waste from the smallest scope i.e. own house;

g) To use technology in coping with less supporting geographical condition for household waste management;

h) To stimulate community through activities that develop creativity and improve environmental awareness.

3) Operational issues:

a) To be committed to implement management of household waste through social assistance;

b) To support and implement program of Work Team of Water Supply and Environmental Sanitation $(A M P L)$ in waste management;

c) To be committed to continue making efforts to make change in management of household waste.

Supporting and Inhibiting Factors of Strategy of Local Government in Management of Household Waste are as follows:

1) Supporting Factors

a) Diverse nature of manpower that is responsible for the duties charged;

b) Technology with positive impacts in facilitating management of household waste;

c) Economic shock as opportunity to encourage emergence of ideas and innovations in waste management in order to improve social economy; 
d) Competition as strength for organization to boost improvement of services, especially of household waste management;

e) Social trend of accessible growing information;

2) Inhibiting Factors

a) Habit of the people who improperly dispose of waste;

b) Social change in a community that affects social attitudes and behaviors among groups of community;

c) Structural weaknesses in organization, including quality of human resources;

d) Lack of skills of the employees as a threat for organizational survivability;

e) Threat on allocation of supporting resources for activities of household waste management.

Efforts to overcome the inhibiting factors in Strategy of Local Government in Management of Household Waste are as follows:

1) Overcoming the inhibiting factors in waste management can be done through education and communication to improve ability and knowledge of employees;

2) Establish participation of multiple parties through promotion and providing of reward in waste management activities;

3) Prepare employees and emphasizes on commitment and support on organization as a whole to help them emotionally to accept changes in waste management;

4) Establish rapport between government and community to develop public trust towards government;

5) Existence of coercion emphasizes the enforcement of all rules that have been made and giving of sanction to those who fail to comply;

Providing of facilities and infrastructures in waste management will have positive impacts on operational activities of organization.

\section{Recommendation}

Along with the conclusions, it is necessary to give input of recommendations as consideration for strategy of Local Government in management of household waste in Jatinangor District, Sumedang Regency, West Java Province, i.e.:

Based on the conclusions about strategy of Local Government in household waste management in Jatinangor District, Sumedang Regency, West Java Province, below are recommendations given:

1) Strengths

a) Enactment of Regional Regulation of Sumedang Regency No. 2 of 2004 on Management of Household Waste and Other Similar Types of Waste in Sumedang Regency;

b) Realization of commitment that has been made according to work program;

c) Establish Memorandum of Understanding (MOU) between Komunitas 
Peduli Sampah Jatinangor (KPS) and Government as basis for implementation of waste management duty;

d) Each society of academicians should prepare human resource with environmental awareness;

e) Apparatus should deliver services and perform breakthrough movement in management of household waste;

2) Weaknesses

a) Organize job structure according to competence of each official;

b) Provide necessary supporting facilities and infrastructures for operational activities of waste management;

c) Cooperate with apparatus of each village to promote regional regulation on waste management to community;

d) Provide necessary technology of waste management and prepare necessary human resources who understand the technology as the operator;

e) Encourage community to perform waste management through environmental cleanliness movement.

3) Opportunities

a) Establish Memorandum of Understanding (MOU) on management of household waste between government and private sector;

b) By means of regulation on waste management, make use of budget support to implement programs of household waste management;

c) Work team for water supply and environmental sanitation (AMPL) should synergize activities of waste management to every district in Sumedang Regency;

d) Promote and implement program of community-based total sanitation program (STBM);

e) Run study together with research institutions, such as Bandung Technological Institute (Institut Teknologi Bandung or ITB).

4) Threats

a) Reduce waste production by using reuseable products;

b) Review the spatial planning for Jatinangor area;

c) Minimize effect of waste by sorting and disposing of waste properly;

d) Establish waste processing site $(T P A)$ with fast road access from Jatinangor area;

e) Limit waste production in each house, and make use of waste by recycling.

Based on strategy of Local Government in management of household waste through SWOT matrix analysis, recommendations that can be given are:

1) S-O (Strengths-Opportunities) strategies are:

a) Make waste bank as village program in order to improve social economy and environmental care;

b) Be committed to implement waste management programs with or with social assistance;

c) Urge to immediate implementation of Memorandum of Understanding 
(MOU) with Komunitas Peduli Sampah Jatinangor (KPS) to help the implementation of community-based total sanitation program;

d) Programs of work team for water supply and environmental sanitation $(A M P L)$ should be implemented in every district in Sumedang Regency;

e) Make cooperation in order to study and determine innovations in management of household waste;

2) W-O (Weaknesses-Opportunities) strategies are:

a) Provide skill training and education for apparatus according to needed sector;

b) Propose facility and infrastructure aid to corporates as part of their corporate social responsibility toward environment;

c) Implement promotion of community-based total sanitation program together with apparatus in a forum, such as at village hall;

d) Provide technology of household waste management along with its training;

e) Facilitate facilities and infrastructures, technology and human resources to support management of household waste in Jatinangor;

3) S-TO (Strengths-Threats) strategies are:

a) Bring own meal box or shopping bag to reduce waste production;

b) Be courageous to start making change in management of household waste;

c) Provide support of facility in operational acitivities of Komunitas Peduli Sampah Jatinangor,

d) Run study between educational institutions in overcoming obstacles in waste management;

e) Improve the role of educational institutions in providing training and outreach programs regarding waste management;

4) W-T (Weaknesses-Threats) strategies are:

a) Training of waste management should not only provided to apparatus but also to community;

b) Every household should have organic and non-organic waste bins to make sorting of waste easier;

c) Implement gradual and continuous promotion to community regarding management of household waste and effect of waste;

d) Establish waste processing site not far from Jatinangor area;

e) Implement waste care movement by giving reward to community.

Based on supporting and inhibiting factors of strategy of Local Government in household waste management in Jatinangor District, Sumedang Regency, West Java Province, below are recommendations given:

1) Supporting Factors

a) Facilitate the needs of employee in implementation of household waste management duty;

b) Make use of technology to access recent information on waste management; 
c) Facilitate waste recycle activities to improve social economy;

d) Make cooperation of training on waste management to improve services and work motivation;

e) Update news on waste management as motivation to seize the opportunity in waste recycle.

2) Inhibiting Factors

a) Change public mindset towards environment through continuous stimuli;

b) Promote communal work as effort to regrow the spirit of togetherness and environmental care;

c) Improve quality of employees by providing skill training accordingly;

d) Provide training according to job analysis in organization;

e) Make plan and proposal of internal needs of the organization.

Based on efforts to overcome the inhibiting factors of strategy of Local Government in household waste management in Jatinangor District, Sumedang Regency, West Java Province, below are recommendations given:

1) Education and communication should be customized accordingly so that capability and knowledge of employees is in line with the needs of each organization;

2) Establish participation of multiple parties through promotion and providing of reward in waste management activities;

3) Emphasis on support and commitment can be by familial approach, but should also be balanced with fulfillment of needs or facilitation, especially in management of household waste;

4) Establishment of rapport based on trust should be firmly held, do not let public disappointed because it will lead to the loss of public trust.

5) Coercion can be compelled as warning, coercion in waste management should still refer to prevailing regulations;

Operational activities of organization will run if supported by facilities and infrastructures according to the needs in management of household waste.

\section{Conflicts of Interest}

The authors declare no conflicts of interest regarding the publication of this paper.

\section{References}

[1] Misitry of Home Affairs (2014) Law No. 23 of 2014 on Local Governmet. Regulation, Indonesia.

[2] Manik, K.E.S. Environmental Management. Djambatan, Jakarta.

[3] Dhokhikah, Y. and Trihadiningrum, Y. Journal Solid Waste Management in Asian Developing Countries: Challenges and Opportunities. https://www.textroad.com/pdf/JAEBS/J.\%20Appl.\%20Environ.\%20Biol.\%20Sci.,\%2 02(7)329-335,\%202012.pdf

[4] Ministry of Home Affairs (2008) Law No. 18 of 2008 on Waste Management. Regulation, Indonesia. 
[5] Sumedang, R. (2015) Study of EHRA (Environment Health Risk Assessment). No. Publish, Sumedang.

[6] Java, W. (2004) Province. Government Regulation No. 81 of 2004 on Management of Houshold Waste and Other Similar Types of Waste. Regulation, Bandung.

[7] Kabarpriangan. https://kabarpriangan.co.id/cecep-lukman-pemkab-tidak-fokus-kelola-sampah-di-j atinangor/

[8] http://eljabar.com/sampah-di-kawasan-jatinangor-berkurang/

[9] Sumedang, R. (2004) Regional Regulation of Sumedang Regency No. 2 of 2004 on Management of Household Waste and Other Similar Type of Waste in Sumedang Regency. Regulation, Sumedang.

[10] Stephen, R.P. and Coulter, M. (2016) Management Vol. 1 Ed. 13. Devri Barnadi Putera Bob Sabran. Translate. Erlangga, Jakarta.

[11] Rangkuti, F. (2014) Technique to Investigate Business Case of SWOT Analysis. PT, Jakarta, Gramedia Pustaka Utama.

[12] Simangunsong, F. (2016) Methodology of Public Administration Research. Alfabeta, Bandung.

[13] Bryson, J.M. (2016) Strategic Planning for Social Organization. Miftahudin, M., Translated. Pustaka Pelajar, Yogyakarta. 